Research Paper

\title{
Effect of Low-Level Laser Therapy on Incorporation of Block Allografts
}

Renato Valiati ${ }^{1,2}$, Jefferson Viapiana Paes ${ }^{1,2}$, Aury Nunes de Moraes ${ }^{3}$, Aldo Gava ${ }^{3}$, Michelle Agostini ${ }^{1}$, Anelise Viapiana Masiero ${ }^{1}$, Marilia Gerhardt de Oliveira ${ }^{4}$, Rogério Miranda Pagnoncelli ${ }^{5}$

1. School of Dentistry, Universidade do Planalto Catarinense (UNIPLAC), Lages, Brazil;

2. School of Dentistry, Pontifícia Universidade Católica do Rio Grande do Sul (PUC-RS), Porto Alegre, Brazil;

3. Universidade do Estado de Santa Catarina (UDESC), Lages, Brazil;

4. Oral and maxillofacial surgery department, PUC-RS, Porto Alegre, Brazil;

5. Dental surgery department, PUC-RS, Porto Alegre, Brazil.

$\square$ Corresponding author: Renato Valiati, Rua Vicente Gamborgi 111, apto 302, bloco 2, 88.501-125 - Lages - SC - Brazil. Phone: +55 493221 7100, E-mail: renato.valiati@gmail.com.

(C) Ivyspring International Publisher. This is an open-access article distributed under the terms of the Creative Commons License (http://creativecommons.org/ licenses/by-nc-nd/3.0/). Reproduction is permitted for personal, noncommercial use, provided that the article is in whole, unmodified, and properly cited.

Received: 2012.04.04; Accepted: 2012.10.30; Published: 2012.11.05

\begin{abstract}
Objective To assess the effect of low-level laser therapy (LLLT) on the incorporation of deep-frozen block allografts in a rabbit model.

Background Data Studies have shown that LLLT has beneficial effects on tissue repair and new bone formation.

Methods Bone tissue was harvested from two rabbits, processed by deep-freezing and grafted into the calvaria of 12 animals, which were then randomly allocated into two groups: experimental $(L)$ and control $(C)$. Rabbits in group $L$ were irradiated with an aluminum gallium arsenide diode laser (AIGaAs; wavelength $830 \mathrm{~nm}, 4 \mathrm{~J} / \mathrm{cm}^{2}$ ), applied to four sites on the calvaria, for a total dose of $16 \mathrm{~J} / \mathrm{cm}^{2}$ per session. The total treatment dose after eight sessions was $128 \mathrm{~J} / \mathrm{cm}^{2}$. Animals were euthanized at $35(n=6)$ or 70 days $(n=6)$ postoperatively.

Results Deep-freeze-processed block allografts followed by LLLT showed incorporation at the graft-host interface, moderate bone remodeling, partial filling of osteocyte lacunae, less inflammatory infiltrate in the early postoperative period, and higher collagen deposition than the control group.

Conclusion Optical microscopy and scanning electron microscopy showed that allograft bone processed by deep-freezing plus LLLT is suitable as an alternative for the treatment of bone defects. Use of the deep-freezing method for processing of bone grafts preserves the structural and osteoconductive characteristics of bone tissue.
\end{abstract}

Key words: Bone healing; Diode/diode laser; Effect of lasers in tissue; Low-level laser therapy.

\section{INTRODUCTION}

One of the main objectives of dentistry is rehabilitation of the stomatognathic system, restoring form, function, cosmesis, phonation, and self-esteem in individuals who have suffered tissue loss due to trauma, disease, atrophy, surgical intervention, or congenital defects.
When a fracture occurs, an osseointegrated implant is placed, or a graft is used for bone augmentation prior to implant placement. The purpose is induction of bone regeneration, that is, the formation of new bone that, after undergoing remodeling processes, is identical to preexisting tissue. ${ }^{1}$ 
Bone is the second most widely transplanted of all tissues; only blood is transplanted or transfused more often. Over 2.2 million bone grafts are placed worldwide every year, 450,000 in the United States alone. $^{2}$

Autogenous tissue is the ideal substrate for bone augmentation, but harvesting procedures increase operative time and cost and require a second surgical field, which may increase postoperative discomfort. The limited quantity of autogenous tissue that can be obtained from intraoral sites such as the maxillary tuberosity, extraction areas, edentulous alveolar ridge, symphysis menti, ramus, and retromolar space also poses a challenge. ${ }^{3}$ For these and other reasons, researchers are increasingly searching for alternative approaches or biomaterials that might circumvent these hurdles and reduce surgical morbidity. The advantages of allograft bone include greater availability, avoidance of a second surgical field, prevention of donor site morbidity, lower treatment costs, and improved patient acceptance. ${ }^{4}$

During the first hundred years (1880-1980) of allograft use, the main issue was availability, as there was no legislation in place to protect tissue processing and tissue donors. During the two decades that followed (1980-2000), safety became the number-one issue. Preventing disease transmission became a prime concern. More sensitive blood testing and major efforts on the part of tissue banks to develop better mechanisms for graft cleansing and removal of infectious agents have helped enable safe bone transplantation, and the key concern is now the efficacy of bone grafts. $^{5}$

Incorporation may be defined as the process of union between graft material and host tissue. Bone graft incorporation involves a cascade of events similar to the stages of fracture consolidation. ${ }^{6,7}$ Regardless of graft type, incorporation is preceded by a sequential process, which may be divided - for educational purposes - into the stages of inflammation, revascularization, osteoinduction, osteoconduction, and remodeling. ${ }^{8}$

Allograft bone is necrotic, and incorporation to adjacent bone occurs through identification of necrotic bone spicules (lacking cells in the osteocyte lacunae) bounded by the cementing lines of new bone formation. This process, known as creeping substitution, mimics the way in which necrotic bone is resorbed and neoformed. ${ }^{9}$

Incorporation of allogeneic bone is slower than that of autologous bone at the graft-host interface, as it involves a stronger initial inflammatory reaction and less revascularization and because allogeneic bone plays no role in the early stages of incorporation-due to its absence of osteogenic function, allograft bone is entirely reliant on the host site to provide the vital substrate for this stage., ${ }^{70-12}$ Allogeneic bone appears to act more as a mineral matrix or scaffold that supports cell migration and proliferation. ${ }^{13}$

The growing popularity of dental implants increased the possibility of treating dental loss. Dental care professionals also began to seek excellence in cosmetic results, due to increasingly discerning and demanding patients. In case of major bone loss at the alveolar ridge, implant placement usually must be preceded by bone grafting to restore function, form, and cosmesis. ${ }^{14-18}$

Restorative-driven or backwards planning, in which implant placement is determined by the ideal position of the crown for optimal function and cosmesis, is the mainstay of current dental implant treatment. ${ }^{18}$ This approach sometimes requires the use of bone grafts to correct alveolar ridge defects and thus enable optimal implant placement. ${ }^{4,17,19}$

Several methods are available to improve bone repair, including the use of grafts and laser therapy. ${ }^{20}$ Use of the latter began empirically in the 1960s, and has since gained credibility and adherents worldwide. Over the past two decades, several studies on the theme have been published in scientific journals, enabling evidence-based clinical use of laser therapy. ${ }^{21}$

The present study thus sought to assess the effect of low-level laser therapy on deep-frozen block allograft incorporation in the rabbit calvaria, comparing irradiated and non-irradiated sites.

\section{MATERIALS AND METHODS}

This study was approved by the Universidade do Estado de Santa Catarina (UDESC) Animal Experimentation Ethics Committee with judgment no. 1.04/08 and by the Ethics of Animal Use Committee of the Pontifícia Universidade Católica do Rio Grande do Sul with registry number CEUA/PUCRS 09/00112.

The animal model chosen for this study was the New Zealand rabbit (Oryctolagos cuniculus). A total of 14 adult female rabbits (age 8-10 months, weight $3.5-4.5 \mathrm{~kg}$ ) were used in the study. Selected animals were kept at the UDESC vivarium for the duration of the experiment. Care and feeding were provided according to standard vivarium practices.

Two rabbits were used as bone donors. Twelve were randomly allocated into two groups, L (experimental) and C (control), and received allogeneic bone grafts.

After measurement of weight and several clinical parameters (including respiratory rate, heart rate, and capillary refill), animals were premedicated with 
tiletamine/zolazepam (Zoletil $100^{\circledR}$, Virbac Saude Animal, São Paulo, Brazil) $20 \mathrm{mg} / \mathrm{kg}$ and xylazine (Anasedan ${ }^{\circledR}$, Vetbrands Saude Animal, Brazil) 3 $\mathrm{mg} / \mathrm{kg}$ IM. Animals were then placed in sternal recumbency on an active warming blanket and the marginal ear vein was cannulated with a 24-gauge catheter for administration of normal saline. Anesthesia was maintained with 1.0-1.5 MAC isoflurane (Isoforine ${ }^{\circledR}$, Cristália Produtos Químicos e Farmacêuticos Ltda., São Paulo, Brazil), provided through a non-rebreather mask, diluted in $100 \%$ oxygen (2 $\mathrm{L} / \mathrm{min}$ ) in a universal anesthetic vaporizer ( Oxygel ${ }^{\circledR}$, São Paulo, Brazil). The frontoparietal region was further anesthetized with local infiltration of $0.5 \mathrm{~mL}$ plain lidocaine (2\%) (Xylestesin ${ }^{\circledR} 2 \%$, Cristália Produtos Químicos e Farmacêuticos Ltda, São Paulo, Brazil).

The surgical field was disinfected with povidone-iodine (Povidine ${ }^{\circledR}$ ) and isolated with sterile drapes.

A $5 \mathrm{~cm}$-long, full thickness incision was made down to the periosteum overlying the sagittal suture and center of the frontal bone with a \#15 blade. Soft tissues were dissected with a Freer elevator (Golgran $^{\circledR}$, São Paulo, Brazil).

Grafts were harvested from the calvaria with a straight handpiece (Kavo ${ }^{\circledR}$ Brasil Ind. e Com. Ltda) set to $800 \mathrm{rpm}$ and an $8 \mathrm{~mm}$ trephine (Neodent ${ }^{\circledR}$, Curitiba, Brazil), under copious irrigation with saline solution . Graft blocks were carefully lifted with a Freer elevator.

Six bone blocks were harvested from the calvaria of each donor rabbit, for a total of 12 block allografts.

Block allografts were thoroughly washed with saline solution, cleaned of any soft tissues, placed into sterile containers and frozen at $-70^{\circ} \mathrm{C}$. Grafts were then kept deep-frozen for 30 days prior to implantation.

After 30 days, host rabbits were prepped and anesthetized as noted above. Incision and flap raising were also as in the first procedure.

Allografts were thawed in saline at room temperature, drilled through with a $1.6-\mathrm{mm}$ bit (Neodent $\left.{ }^{\circledR}\right)$, and fastened to the cranial vault with a 1.5 $\mathrm{mm} \times 6 \mathrm{~mm}$ self-tapping screw (Neodent ${ }^{\circledR}$ ) on the right, using a conventional Philips screwdriver (Neodent $(\mathbb{8})$. Eight-millimeter pieces of bone were trephined from a more anterior region of the skull vault and placed on the left (opposite the experimental site) to serve as an autogenous positive control for bone incorporation. Screws were anchored bicortically.

The wound bed was copiously irrigated with saline solution and the incision was closed with simple running sutures (Ethicon® 5-0 nylon).
Antimicrobial coverage was provided with enrofloxacin $5 \mathrm{mg} / \mathrm{kg}$ IM once daily. Postoperative analgesia consisted of meloxicam $0.1 \mathrm{mg} / \mathrm{kg}$ once daily, with rescue tramadol $2 \mathrm{mg} / \mathrm{kg}$ (Tramadon ${ }^{\circledR}$ $50 \mathrm{mg} / \mathrm{ml}$, Cristália Produtos químicos e Farmacêuticos Ltda, São Paulo, Brazil) as needed in case of intense pain.

Immediately after conclusion of the procedure, animals in group L (experimental) underwent infrared laser irradiation with aluminum gallium arsenide diode laser (AlGaAs; wavelength $830 \mathrm{~nm}$; Thera Lase ${ }^{\circledR}$, DMC Equipamentos Ltda., Brazil), which was subsequently repeated every 48 hours for a total of eight sessions.

The laser was applied to four sites (anterior, posterior, left lateral and right lateral aspects of the cranial vault) at an energy density of $4 \mathrm{~J} / \mathrm{cm}^{2}$, for a total dose of $16 \mathrm{~J} / \mathrm{cm}^{2}$ per session. The total dose after eight sessions was therefore $128 \mathrm{~J} / \mathrm{cm}^{2}$.

Animals in group C (control) underwent sham irradiation, with the laser unit switched off, to simulate the stress of restraint.

Six animals were euthanized at 35 days post-graft implantation, and the remaining six at 70 days. Anesthesia was induced with tiletamine/zolazepam $20 \mathrm{mg} / \mathrm{kg}$ and xylazine $3 \mathrm{mg} / \mathrm{kg}$ $\mathrm{IM}$, followed by a lethal injection of $300 \mathrm{mg}$ potassium chloride (Cristália Produtos Químicos e Farmacêuticos Ltda., São Paulo, Brazil) into the marginal ear vein.

The surgical site was dissected and a $10-\mathrm{mm}$ trephine bit was used to obtain a sample of bone containing the graft and host tissue margins. Specimens were kept in 10\% buffered formalin solution for 48 hours, decalcified in 5\% aqueous nitric oxide, and bisected lengthwise with a microtome knife.

Specimens then underwent routine processing; $5-\mu \mathrm{m}$ thick longitudinal slices were obtained and stained with hematoxylin and eosin (H\&E).

The other half of each sample was sent for scanning electron microscopy (SEM) at the Pontifícia Universidade Católica do Rio Grande do Sul (PUCRS) Microscopy and Microanalysis Center. Samples were attached to specimen holders with double-stick carbon tape, sputter coated with gold, and placed in a vacuum chamber for observation under a scanning electron microscope.

Assessment of the effects of laser therapy was based on descriptive, semiquantitative histological analysis based on the methods proposed by Weber et al. ${ }^{20}$, Torres et al. ${ }^{22}$ and Pinheiro et al. ${ }^{23}$

Fisher's exact test was used for statistical analyses. The significance level was set at 5\% (95\%; $p<$ 0.05). 


\section{RESULTS \\ HISTOLOGICAL TESTING}

Descriptive, semiquantitative, light microscopy-based histological assessment

Histological assessment showed significant changes, particularly regarding filling of osteocyte lacunae, replacement of graft myeloid tissue with fibrocollagenous tissue, inflammatory reaction (with a macrophage and neutrophil infiltrate), bone remodeling, and neovascularization. There were significant between-group differences in these changes. Incorporation at the graft-host interface was good in both groups.

Allograft group (35 days): Collagen fiber deposition was visible throughout the medullary spaces in both groups (moderate in the LLLT group and mild to moderate in the control group). Bone remodeling was also evident in both groups (mild to moderate in the LLLT group and mild in the control group). In both groups, osteocyte lacunae were mostly filled at the graft-to-host interface, while the surface, center, and periphery of the trabeculae were empty in most lacunae. Mononuclear leukocyte and neutrophil infiltration of the medullary spaces was present in both groups. The inflammatory reaction was mild in the irradiated group and mild to moderate in the control group (Table 2).

Allograft group (70 days): Collagen fibers were present in moderate to marked density in the medullary spaces of irradiated grafts and in slight to moderate density in the control group. Bone remodeling was moderate in the LLLT group and mild in the control group. Lacunae at the graft-to-host interface and surface of irradiated grafts were mostly filled with osteocytes, whereas only moderate filling was visible in the center of the graft. In the control group, most lacunae were empty in the center and periphery, and partially filled at the graft-to-host interface. Mild inflammatory reaction with a macrophage and neutrophil infiltrate was present in both groups (Table 3).
Autograft group (35 days): In both groups, deposition of collagen fibers ranged from mild to moderate in intensity. Bone remodeling was moderate to marked in the experimental group and mild to moderate in controls. Most osteocyte lacunae were filled in the irradiated group, whereas lacunae in control grafts were filled mostly at the graft-host interface and surface, with most lacunae empty at the center. Mild-to-moderate inflammatory infiltrates were present in both groups (Table 4).

Autograft group (70 days): In the irradiated group, deposition of collagen fibers ranged from mild to marked. In the control group, fibers were seen only in some specimens, and never at a moderate or higher density. Moderate to marked bone remodeling was present in the irradiated group, and moderate remodeling in the control group. Most osteocyte lacunae were filled in irradiated group grafts, whereas lacunae in control grafts were mostly filled at the graft-host interface, at the surface, and, to a lesser extent, in the core area (Table 5).

Scanning electron microscopy (SEM) and optical microscopy (OM)-based assessment of incorporation at the graft-host interface

SEM at 45x (Figure $1 \mathrm{~A}$ and $\mathrm{B}$ ) and 500x magnification and optical microscopy at 40x magnification and 100x magnification (Figures $2 \mathrm{~A}$ and B, $3 \mathrm{~A}$ and B, $4 \mathrm{~A}$ and $\mathrm{B}$ and $5 \mathrm{~A}$ and $\mathrm{B}$ ) clearly showed graft incorporation at the graft-host interface in all speciments. In areas of cortical bone, grafts were in close contact with recipient areas; filling of osteocyte lacunae was evident, as were medullary degeneration, necrosis and revascularization in the medullary spaces at the graft-host interface, with deposition of collagen fibers and bone remodeling.

Assessment showed the osteoconductive properties of block allografts are preserved after deep-freezing, as are their structural characteristics and bone matrix, providing a scaffold for host-to-graft migration of blood vessels and cells.

Table I. Semiquantitative criteria for light microscopy assessment of histological specimens.

\begin{tabular}{|c|c|c|c|c|c|}
\hline & $\begin{array}{l}\text { Collagen fiber } \\
\text { deposition }\end{array}$ & Bone remodeling & $\begin{array}{l}\text { Filling of osteocyte } \\
\text { lacunae }\end{array}$ & $\begin{array}{l}\text { Incorporation at the } \\
\text { graft-host interface }\end{array}$ & Inflammatory infiltrate \\
\hline None & 0 & 0 & 0 & 0 & 0 \\
\hline Mild/Slight & + & + & + & + & + \\
\hline Moderate & ++ & ++ & ++ & ++ & ++ \\
\hline Marked & +++ & +++ & +++ & +++ & +++ \\
\hline
\end{tabular}


Table 2. Assessment of allograft group at 35 days, control (C) and experiment (L) animals.

\begin{tabular}{|c|c|c|c|c|c|}
\hline & $\begin{array}{l}\text { Collagen fiber } \\
\text { deposition }\end{array}$ & Bone remodeling & $\begin{array}{l}\text { Filling of osteocyte } \\
\text { lacunae }\end{array}$ & $\begin{array}{l}\text { Incorporation at the } \\
\text { graft-host interface }\end{array}$ & $\begin{array}{l}\text { Inflammatory infil- } \\
\text { trate }\end{array}$ \\
\hline 1- C1, allograft, $35 \mathrm{~d}$ & + & + & + & +++ & ++ \\
\hline 2- C2, allograft, $35 \mathrm{~d}$ & ++ & + & + & +++ & + \\
\hline 3- C3, allograft, $35 \mathrm{~d}$ & + & + & ++ & +++ & +++ \\
\hline 4- L1, allograft, $35 \mathrm{~d}$ & ++ & + & + & +++ & + \\
\hline 5- L2, allograft, $35 \mathrm{~d}$ & ++ & ++ & ++ & +++ & + \\
\hline 6- L3, allograft, $35 \mathrm{~d}$ & ++ & ++ & + & +++ & + \\
\hline
\end{tabular}

Table 3. Assessment of allograft group at 70 days, control (C) and experiment (L) animals.

\begin{tabular}{|c|c|c|c|c|c|}
\hline & $\begin{array}{l}\text { Collagen fiber } \\
\text { deposition }\end{array}$ & Bone remodeling & $\begin{array}{l}\text { Filling of osteocyte } \\
\text { lacunae }\end{array}$ & $\begin{array}{l}\text { Incorporation at the } \\
\text { graft-host interface }\end{array}$ & Inflammatory infiltrate \\
\hline 7- C1, allograft, $70 \mathrm{~d}$ & + & + & + & +++ & + \\
\hline 8- C2, allograft, $70 \mathrm{~d}$ & ++ & + & + & +++ & + \\
\hline 9- C3, allograft, $70 \mathrm{~d}$ & ++ & + & + & +++ & + \\
\hline 10- L1, allograft, $70 \mathrm{~d}$ & ++ & ++ & ++ & +++ & + \\
\hline 11- L2, allograft, $70 \mathrm{~d}$ & ++ & ++ & ++ & +++ & + \\
\hline 12- L3, allograft, $70 \mathrm{~d}$ & +++ & ++ & + & +++ & + \\
\hline
\end{tabular}

Tabela 4. Assessment of autograft group at 35 days, control $(\mathrm{C})$ and experiment $(\mathrm{L})$ animals.

\begin{tabular}{|c|c|c|c|c|c|}
\hline & $\begin{array}{l}\text { Collagen fiber } \\
\text { deposition }\end{array}$ & Bone remodeling & $\begin{array}{l}\text { Filling of osteocyte } \\
\text { lacunae }\end{array}$ & $\begin{array}{l}\text { Incorporation at the } \\
\text { graft-host interface }\end{array}$ & Inflammatory infiltrate \\
\hline 13-C1, autograft, $35 \mathrm{~d}$ & ++ & ++ & ++ & +++ & ++ \\
\hline $14-\mathrm{C} 2$, autograft, $35 \mathrm{~d}$ & + & + & ++ & +++ & + \\
\hline $15-C 3$, autograft, $35 \mathrm{~d}$ & + & ++ & ++ & +++ & + \\
\hline 16-L1, autograft, $35 \mathrm{~d}$ & ++ & ++ & ++ & +++ & ++ \\
\hline 17- L2, autograft, $35 \mathrm{~d}$ & + & ++ & +++ & +++ & + \\
\hline 18- L3, autograft, $35 \mathrm{~d}$ & ++ & ++ & +++ & +++ & + \\
\hline
\end{tabular}

Table 5. Assessment of allograft group at 70 days, control (C) and experiment (L) animals.

\begin{tabular}{|c|c|c|c|c|c|}
\hline & $\begin{array}{l}\text { Collagen fiber dep- } \\
\text { osition }\end{array}$ & Bone remodeling & $\begin{array}{l}\text { Filling of osteocyte } \\
\text { lacunae }\end{array}$ & $\begin{array}{l}\text { Incorporation at the } \\
\text { graft-host interface }\end{array}$ & Inflammatory infiltrate \\
\hline 19-C1, autograft, $70 \mathrm{~d}$ & + & ++ & ++ & +++ & 0 \\
\hline 20-C2, autograft, $70 \mathrm{~d}$ & + & ++ & ++ & +++ & 0 \\
\hline 21-C3, autograft, $70 \mathrm{~d}$ & 0 & ++ & ++ & +++ & 0 \\
\hline 22-L1, autograft, $70 \mathrm{~d}$ & +++ & ++ & ++ & +++ & 0 \\
\hline 23-L2, autograft, $70 \mathrm{~d}$ & + & +++ & +++ & +++ & 0 \\
\hline 24-L3, autograft, $70 \mathrm{~d}$ & + & +++ & +++ & +++ & 0 \\
\hline
\end{tabular}



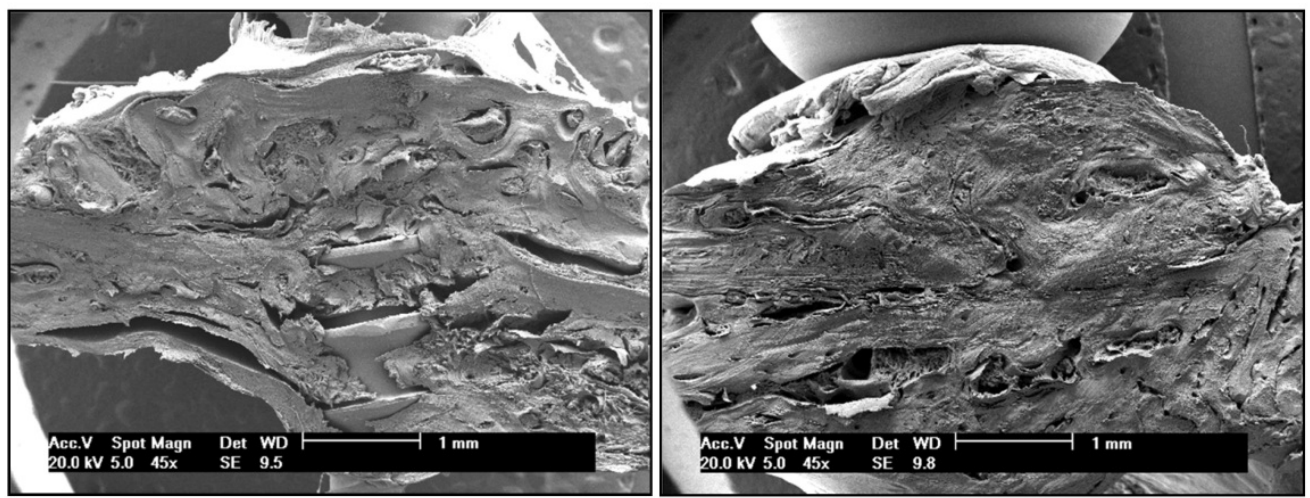

Figure I. A - Bone allograft at 70 days, LLLT group. B - Bone autograft at 70 days, control group. SEM clearly showed graft incorporation at the graft-host interface in all speciments.
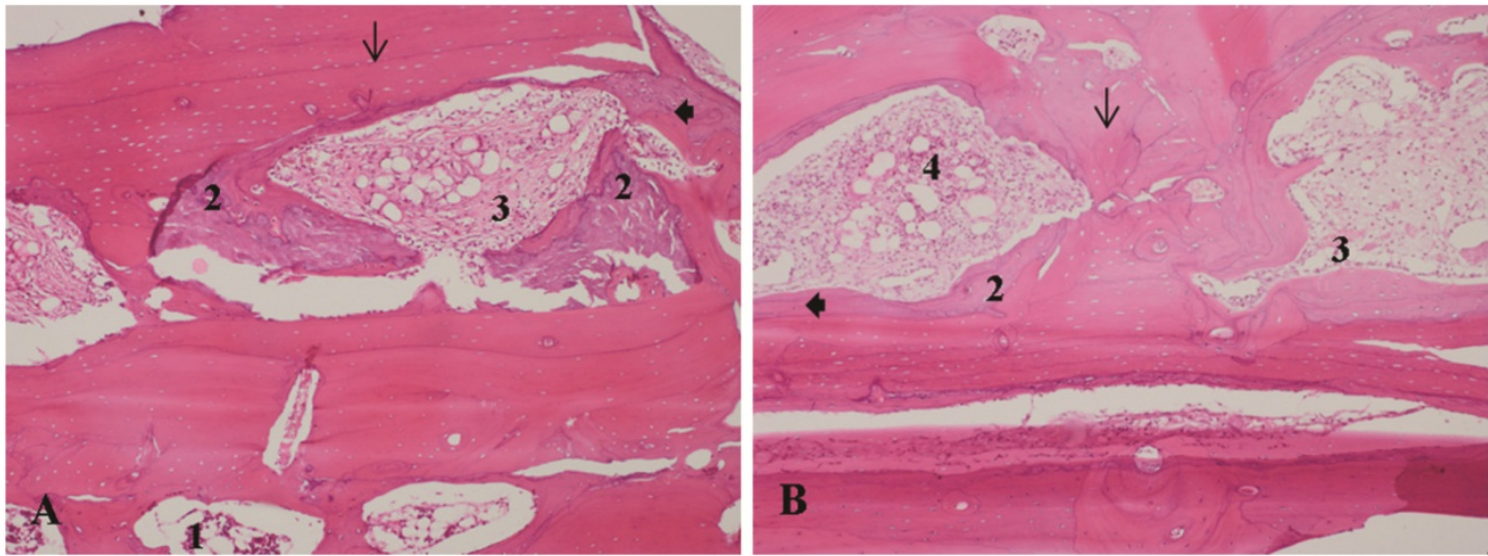

Figure 2. A - Bone allograft at 35 days, LLLT group. B - Bone allograft at 35 days, control group. I-Recipient tissue, showing normal bone marrow. 2- Bone remodeling. 3 - Proliferation of collagen fibers. 4 - Inflammatory infiltrate. Arrow: osteocyte lacunae. Arrowhead: filled osteocyte lacunae. H\&E stain, I0x magnification.
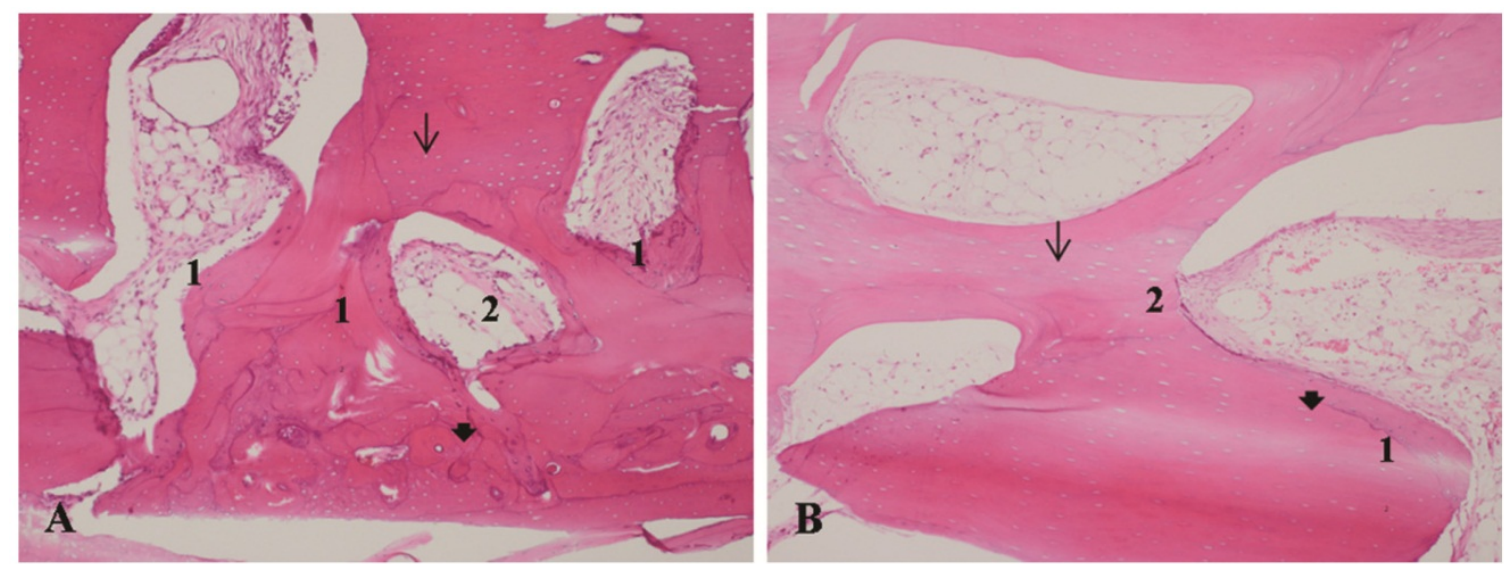

Figure 3. A - Bone allograft at 70 days, LLLT group. B - Bone allograft at 70 days, control group. I- Bone remodeling. 2 - Proliferation of collagen fibers. Arrow: osteocyte lacunae. Arrowhead: filled osteocyte lacunae. H\&E stain, I0x magnification. 

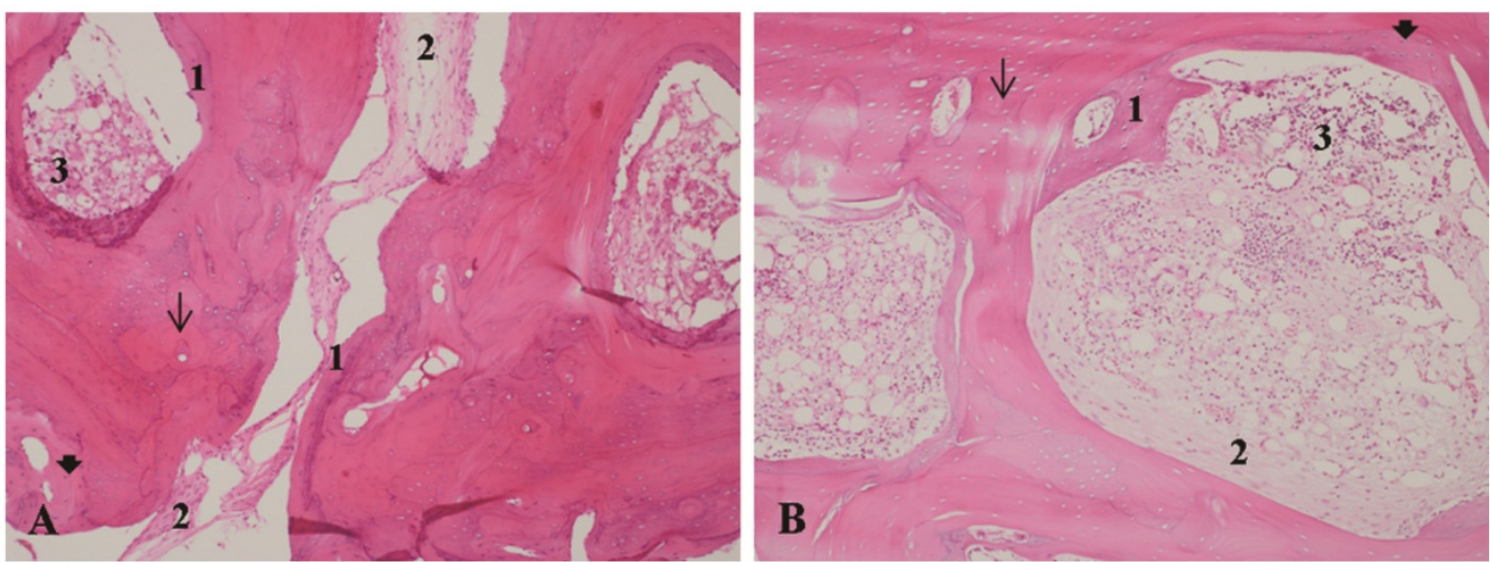

Figure 4. A - Bone autograft at 35 days, LLLT group. B - Bone autograft at 35 days, control group. I- Bone remodeling. 2 - Proliferation of collagen fibers. 3 - Inflammatory infiltrate. Arrow: osteocyte lacunae. Arrowhead: filled osteocyte lacunae. H\&E stain, I0x magnification.
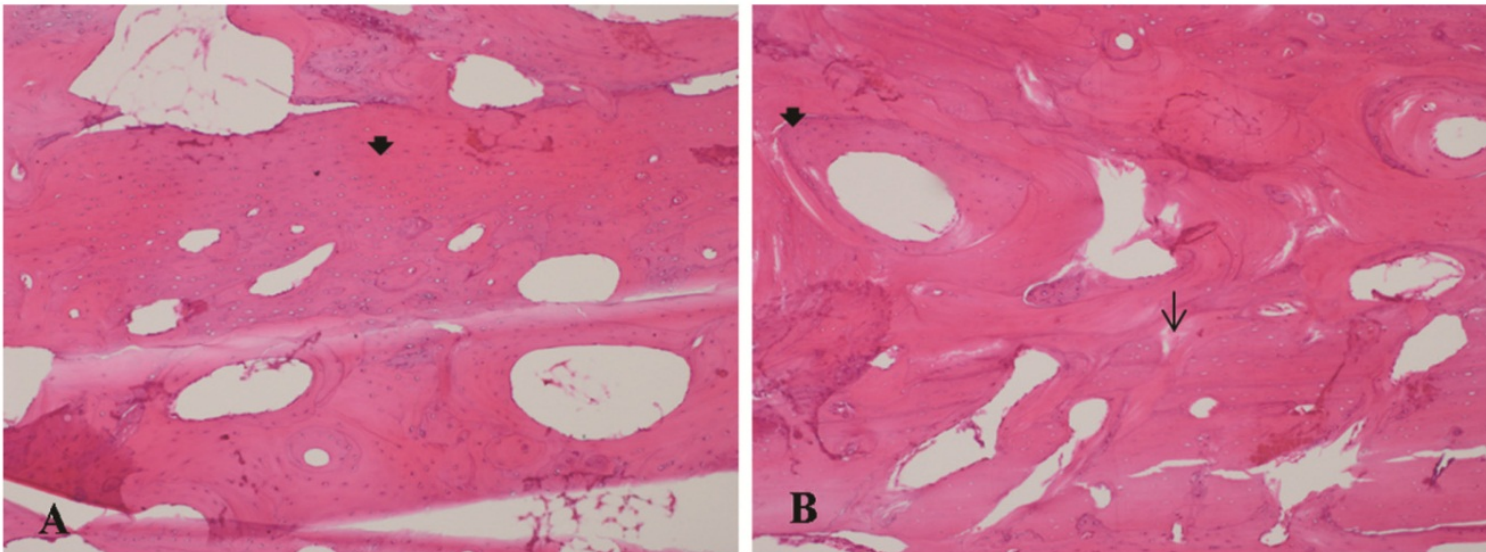

Figure 5. A - Bone autograft at 70 days, LLLT group. B - Bone autograft at 70 days, control group. Normal morphological appearance, with most osteocyte lacunae filled. Arrow: osteocyte lacunae. Arrowhead: filled osteocyte lacunae. H\&E stain, I0x magnification.

\section{DISCUSSION}

A variety of methods have been studied as potential means of improving the speed and quality of allograft incorporation, including platelet-rich plasma (PRP), $, 34,25$ bone morphogenetic proteins (BMPs), 5 bisphosphonates, ${ }^{26}$ adjuvant stem cell and gene therapy, ${ }^{27}$ and processing techniques, such as laser drilling and partial demineralization of block allografts. ${ }^{28}$ Several studies using various graft materials have shown that infrared laser therapy stimulates osteoblast proliferation, collagen deposition, and new bone formation. 29,30

In this study, allogeneic bone tissue was processed by deep freezing. This proved to be an adequate method for allografts, preserving the osteoconductive and structural properties of the graft tissue as a scaffold for vessel and cell proliferation, as demonstrated by partial filling of osteocyte lacunae, early-stage bone remodeling, and incorporation at the graft-host interface. The use of other methods, such as freeze-drying, demineralization, gamma irradiation, ethylene oxide, or hydrogen peroxide, can jeopardize the structural properties of the donor tissue, which are of the utmost importance in onlay grafting. $9,12,13,31-37$

In the present study, collagen deposition was greater in allogeneic and autogenous blocks exposed to laser irradiation. This was consistent with the findings of Pinheiro et al. ${ }^{38}$, Lopes et al. ${ }^{39}$ and Lopes et al. ${ }^{40}$.

Statistical comparisons of all LLLT groups versus controls showed a positive effect of LLLT on bone remodeling $(p=0.0269)$. Bone remodeling was significantly predominant $(\mathrm{p}=0.0151)$ in irradiated allograft groups versus controls at 35 and 70 days. This finding is consistent with that of several prior studies that have shown greater bone remodeling after laser 


\section{therapy. ${ }^{38-46}$}

Filling of osteocyte lacunae was also greater in the laser group, most markedly at 70 days in the allograft group and at 35 and 70 days in the autograft group, providing evidence of partial allograft bone vitality and preserved osteoconduction during this brief experiment. Dörtbudak et al. ${ }^{42}$ and Jakse et al. ${ }^{47}$ both reported a similar effect on autogenous grafts.

Statistical analysis showed greater filling of osteocyte lacunae $(p=0.0009)$ and greater bone remodeling ( $p=0.0267$ ) in autogenous grafts (positive controls) than in allograft blocks. Comparison of the autograft and allograft + LLLT groups showed greater filling of osteocyte lacunae in the autograft group $(\mathrm{p}=$ $0.0375)$, most likely due to transport across the autogenous graft of cells that remained viable during the incorporation stage $\mathrm{e}^{10,11,13}$ and to the biomodulation effects of LLLT on host cells and on graft cells that remained viable in the early stages of bone regeneration, during osteoblast proliferation. ${ }^{48,49}$

Inflammatory reaction in the experimental (irradiated) allograft group at 35 days was less intense than in the control group. There were no significant differences between the other experimental groups and their respective controls.

Animal experiments provide a useful means of estimating tissue reaction to bioactive materials; however, results obtained from animal models should not necessarily be extrapolated to humans. ${ }^{30}$

\section{CONCLUSIONS}

Optical and scanning electron microscopy showed that the combination of deep-frozen bone allografts and LLLT is an adequate alternative for the treatment of bone defects.

After LLLT, deep-freeze-processed bone allografts showed incorporation at the graft-host interface, moderate bone remodeling, partial filling of osteocyte lacunae, less inflammatory infiltrate in the early postoperative period, and higher collagen deposition than the control group, over the course of this brief study.

Use of the deep-freezing method for processing of bone grafts preserves the structural and osteoconductive characteristics of bone tissue.

\section{ACKNOWLEDGEMENTS}

This study was supported by CNPq (Conselho Nacional de Desenvolvimento Científico e Tecnológico - Brazil).

\section{COMPETING INTERESTS}

The authors have declared that no competing interest exists.

\section{REFERENCES}

1. Fernandez-Tresguerres-Hernandez-Gil I, Alobera-Gracia MA, del-Canto-Pingarron M, Blanco-Jerez L. Physiological bases of bone regeneration I. Histology and physiology of bone tissue. Med Oral Patol Oral Cir Bucal. 2006;11(1):E47-51.

2. Betz RR. Limitations of autograft and allograft: new synthetic solutions. Orthopedics. 2002;25(5 Suppl):s561-70.

3. Sanchez AR, Sheridan PJ, Kupp LI. Is platelet-rich plasma the perfect enhancement factor? A current review. Int J Oral Maxillofac Implants. 2003;18(1):93-103.

4. Keith JDJr. Localized ridge augmentation with a block allograft followed by secondary implant placement: a case report. Int J Periodontics Restorative Dent. 2004;24(1):11-7.

5. Tomford WW. Bone allografts: past, present and future. Cell Tissue Bank. 2000;1(2):105-9.

6. Truumees E, Herkowitz H. Alternatives to autologous bone harvest in spine surgery. University of Pennsylvania Orthopaedic Journal. 1999;12:77-88.

7. Zipfel GJ, Guiot BH, Fessler RG. Bone grafting. Neurosurg Focus. 2003;14(2):e8

8. Goldberg VM, Stevenson S. Natural history of autografts and allografts. Clin Orthop Relat Res. 1987;(225):7-16.

9. Bauer TW. An overview of the histology of skeletal substitute materials. Arch Pathol Lab Med. 2007;131(2):217-24.

10. Burchardt H, Jones H, Glowczewskie F, Rudner C, Enneking WF. Freeze-dried allogeneic segmental cortical-bone grafts in dogs. J Bone Joint Surg Am. 1978;60(8):1082-90.

11. Allard RH, Lekkas C, Swart JG. Autologous versus homologous bone grafting in osteotomies, secondary cleft repairs and ridge augmentations: a clinical study. Oral Surg Oral Med Oral Pathol. 1987;64(3):269-74.

12. Nather A. Biology of healing of large deep-frozen cortical bone allografts. In: Phillips GO, editor. Bone Biology and Healing: An Advances in Tissue Banking Specialist Publication. Singapore: World Scientific Publishing. 2003: 47-67.

13. Galea G, Kearney JN. Clinical effectiveness of processed and unprocessed bone. Transfus Med. 2005;15(3):165-74.

14. von Arx T, Cochran DL, Hermann JS, Schenk RK, Buser D. Lateral ridge augmentation using different bone fillers and barrier membrane application. A histologic and histomorphometric pilot study in the canine mandible. Clin Oral Implants Res. 2001;12(3):260-9.

15. Feuille F, Knapp CI, Brunsvold MA, Mellonig JT. Clinical and histologic evaluation of bone-replacement grafts in the treatment of localized alveolar ridge defects. Part 1: Mineralized freeze-dried bone allograft. Int J Periodontics Restorative Dent. 2003;23(1):29-35.

16. Kaufman E, Wang PD. Localized vertical maxillary ridge augmentation using symphyseal bone cores: a technique and case report. Int J Oral Maxillofac Implants. 2003;18(2):293-8.

17. Chiapasco M, Zaniboni M, Boisco M. Augmentation procedures for the rehabilitation of deficient edentulous ridges with oral implants. Clin Oral Implants Res. 17 Suppl 2006;2:136-59.

18. Levandowski JrN, Pfeifer A, Paza A, Valiati R, Silva M. Utilização do osso alógeno em bloco para aumento de rebordo alveolar: revisão da literatura. Revista Implantnews. 2008;5(1):51-7.

19. Wallace S, Gellin R. Clinical evaluation of freeze-dried cancellous block allografts for ridge augmentation and implant placement in the maxilla. Implant Dent. 2010;19(4):272-9.

20. Weber JB, Pinheiro AL, de Oliveira MG, Oliveira FA, Ramalho LM. Laser therapy improves healing of bone defects submitted to autologous bone graft. Photomed Laser Surg. 2006;24(1):38-44.

21. Junior AB. Laser phototherapy in dentistry. Photomed Laser Surg. 2009;27(4):533-4.

22. Torres CS, dos Santos JN, Monteiro JS, Amorim PG, Pinheiro AL. Does the use of laser photobiomodulation, bone morphogenetic proteins, and guided bone regeneration improve the outcome of autologous bone grafts? An in vivo study in a rodent model. Photomed Laser Surg. 2008;26(4):371-7.

23. Pinheiro AL, Martinez Gerbi ME, de Assis Limeira FJr, Carneiro Ponzi EA, Marques AM, Carvalho CM, et al. Bone repair following bone grafting hydroxyapatite guided bone regeneration and infra-red laser photobiomodulation: a histological study in a rodent model. Lasers Med Sci. 2009;24(2):234-40.

24. Jensen TB, Rahbek O, Overgaard S, Soballe K. No effect of platelet-rich plasma with frozen or processed bone allograft around noncemented implants. Int Orthop. 2005;29(2):67-72.

25. Ilgenli T, Dundar N, Kal BI. Demineralized freeze-dried bone allograft and platelet-rich plasma vs platelet-rich plasma alone in infrabony 
defects: a clinical and radiographic evaluation. Clin Oral Investig. 2007;11(1):51-9.

26. DiResta GR, Manoso MW, Naqvi A, Zanzonico P, Smith-Jones P, Tyler $\mathrm{W}$, et al. Bisphosphonate delivery to tubular bone allografts. Clin Orthop Relat Res. 2008;466(8):1871-9.

27. Ehrhart N, Kraft S, Conover D, Rosier RN, Schwarz EM. Quantification of massive allograft healing with dynamic contrast enhanced-MRI and cone beam-CT: a pilot study. Clin Orthop Relat Res. 2008;466(8):1897-904.

28. Lewandrowski KU, Tomford WW, Schomacker KT, Deutsch TF, Mankin HJ. Improved osteoinduction of cortical bone allografts: a study of the effects of laser perforation and partial demineralization. J Orthop Res. 1997;15(5):748-56.

29. Pinheiro AL, Gerbi ME. Photoengineering of bone repair processes. Photomed Laser Surg. 2006;24(2):169-78.

30. Khadra M, Ronold HJ, Lyngstadaas SP, Ellingsen JE, Haanaes HR. Low-level laser therapy stimulates bone-implant interaction: an experimental study in rabbits. Clin Oral Implants Res. 2004;15(3):325-32.

31. Bostrom MP, Seigerman DA. The clinical use of allografts, demineralized bone matrices, synthetic bone graft substitutes and osteoinductive growth factors: a survey study. HSS J. 2005;1(1):9-18.

32. Baptista AD, Sorrilha A, Tormes TAdM, Abdoune YA, Croci AT, de Camargo OP, et al. Estudo histológico dos enxertos ósseos homólogos humanos (a histological study of human allografts). Acta Ortop Bras. 2003;11(4):220-4.

33. Delloye C, Cnockaert N, Cornu O. Bone substitutes in 2003: an overview. Acta Orthop Belg. 2003;69(1):1-8.

34. DePaula CA, Truncale KG, Gertzman AA, Sunwoo MH, Dunn MG. Effects of hydrogen peroxide cleaning procedures on bone graft osteoinductivity and mechanical properties. Cell Tissue Bank. 2005;6(4):287-98.

35. Hofmann A, Konrad L, Hessmann MH, Kuchle R, Korner J, Rompe JD, et al. The influence of bone allograft processing on osteoblast attachment and function. J Orthop Res. 2005;23(4):846-54.

36. Aslan M, Simsek G, Dayi E. The effect of hyaluronic acid-supplemented bone graft in bone healing: experimental study in rabbits. J Biomater Appl. 2006;20(3):209-20.

37. Andrade MG, Sa CN, Marchionni AM, dos Santos Calmon de Bittencourt TC, Sadigursky M. Effects of freezing on bone histological morphology. Cell Tissue Bank. 2008;9(4):279-87.

38. Pinheiro AL, Limeira Junior Fde A, Gerbi ME, Ramalho LM, Marzola C, Ponzi EA. Effect of low level laser therapy on the repair of bone defects grafted with inorganic bovine bone. Braz Dent J. 2003;14(3):177-81.

39. Lopes CB, Pinheiro AL, Sathaiah S, Duarte J, Cristinamartins M. Infrared laser light reduces loading time of dental implants: a Raman spectroscopic study. Photomed Laser Surg. 2005;23(1):27-31.

40. Lopes CB, Pinheiro AL, Sathaiah S, Da Silva NS, Salgado MA. Infrared laser photobiomodulation (lambda $830 \mathrm{~nm}$ ) on bone tissue around dental implants: a Raman spectroscopy and scanning electronic microscopy study in rabbits. Photomed Laser Surg. 2007;25(2):96-101.

41. Cerqueira A, Silveira RL, Oliveira MG, Sant'ana Filho M, Heitz C. Bone tissue microscopic findings related to the use of diode laser $(830 \mathrm{~nm})$ in ovine mandible submitted to distraction osteogenesis. Acta Cir Bras. 2007;22(2):92-7.

42. Dortbudak O, Haas R, Mallath-Pokorny G. Biostimulation of bone marrow cells with a diode soft laser. Clin Oral Implants Res. 2000;11(6):540-5.

43. Nicola RA, Jorgetti V, Rigau J, Pacheco MT, dos Reis LM, Zangaro RA. Effect of low-power GaAlAs laser $(660 \mathrm{~nm})$ on bone structure and cell activity: an experimental animal study. Lasers Med Sci. 2003;18(2):89-94.

44. Gerbi ME, Pinheiro AL, Marzola C, Limeira Junior Fde A, Ramalho LM, Ponzi EA, et al. Assessment of bone repair associated with the use of organic bovine bone and membrane irradiated at $830 \mathrm{~nm}$. Photomed Laser Surg. 2005;23(4):382-8.

45. Merli LA, Santos MT, Genovese WJ, Faloppa F. Effect of low-intensity laser irradiation on the process of bone repair. Photomed Laser Surg. 2005;23(2):212-5.

46. Guimarães K, Oliveira M, Weber J. Fotoengenharia do processo de reparo ósseo induzido pela laserterapia de baixa potencia (GaAlAs): estudo em fêmures de ratos [dissertation]. Porto Alegre: PUC-RS; 2006.

47. Jakse N, Payer M, Tangl S, Berghold A, Kirmeier R, Lorenzoni M. Influence of low-level laser treatment on bone regeneration and osseointegration of dental implants following sinus augmentation. An experimental study on sheep. Clin Oral Implants Res. 2007:18(4):517-24.

48. Silva Junior AN, Pinheiro AL, Oliveira MG, Weismann R, Ramalho LM, Nicolau RA. Computerized morphometric assessment of the effect of low-level laser therapy on bone repair: an experimental animal study. J Clin Laser Med Surg. 2002;20(2):83-7.

49. Campanha BP, Gallina C, Geremia T, Loro RC, Valiati R, Hubler R, et al. Low-level laser therapy for implants without initial stability. Photomed Laser Surg. 2010;28(3):365-9. 